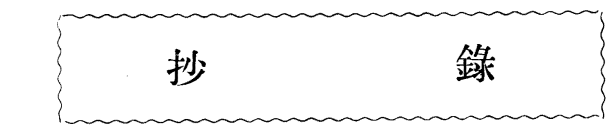

\title{
䓢車の仕上法
}

(American Machinist, June 7, 1933)

梗摡 苳車の仕上には grinding, shaving 及び lapping が多く用みられて居る.この論交はそれ らの方法に關する一般的記述でふる.

荻車の仕上は重要な問題となりつ」ある・そ の發達は自動車工業からの要求による所が多 ん. 自動車に於ては䕨車は多く運轉者の直下に あるから音を立てねととが必要であり，自動車 の值段は安んものであるから，仕上の雼の費用 も安くなければならぬ、齒車に要求せられる靜 肅さと許し得べき磨隇量とは, 茲車の種類及び それが傳達すべき power の大小ルよつて異な る. 仕上の方法とその曘の費用とは蓄の形, 漸 開線苳形に於てはその傾斜角の大いさ, cutting 及び熱處理の方法等によつて影響せられる・品 質の持續と費用の低下に成功するには, 細目に 關する知識, 種々の條件のもとにおける經驗, 適 當な方法の選擇及び職工の訓練が必要である。 靜肅高級な萄車の製作には先づそれを造る鋼 から考へねばならぬ. 炭素及び他金屬の含量, 加熱加工の方法, normalising の方法なビが問 題になる.中心孔が面に垂直であること及び刻 み圓と同心であることが重要である・一度の cutting で荒削りと仕上とを行ふことは推獎で きぬ.

蒛車の嘩合ひを正しくしようとする最初の試

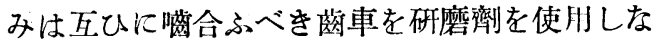
がら伵轉させる゙方法である。之は lapping と 呼ばれることもあるが running-in と言つた方 がよん・粗い研磨劑でこの方法によつて高級な 齔車を造ることは現在殆ど考へられてみない。 併し潤滑齌が非裳に細い研磨劑で最後つ仕上を 行ふ人は二三ある。

Burnishing なるお法もある・燒さを入れ， grinding 及び lapping で正確な形にした master gear と軟かなま〉の green gear とを喝 合はせアイロンをかける樣な作用で正しい形に 直して行く. 3 筬の master gear 当同時に用み るのが普通である・之に對しては大きい壓力の もとで备轉するから齿車の內部に應力を生じ， 燒入れなどの際にそれがもとにもどるととがあ ると言ふ反對者がある・との方法は仕上中の或 階梯として行はれることはあるが，最後の形を 與へることはない。

希望の蒛の外形をしてねる grinding wheel を用みて仕上をすることは 20 年以前から行は れて居る. Grinding wheel の外形は diamond tool で造る.此方法の唱導者はかなり多く medium 及び large size の苳車には適當な方 法の樣である・

或種の蒛車は燒を入れた後に苳を generate 
する grinding wheel で仕上られる. 非常に巧 妙優秀な機械があり， grinding wheel の大き い物を使ふのと小さいのを使ふのと二つの方法 がある，大きいのを使ふ方では面のせまい普通

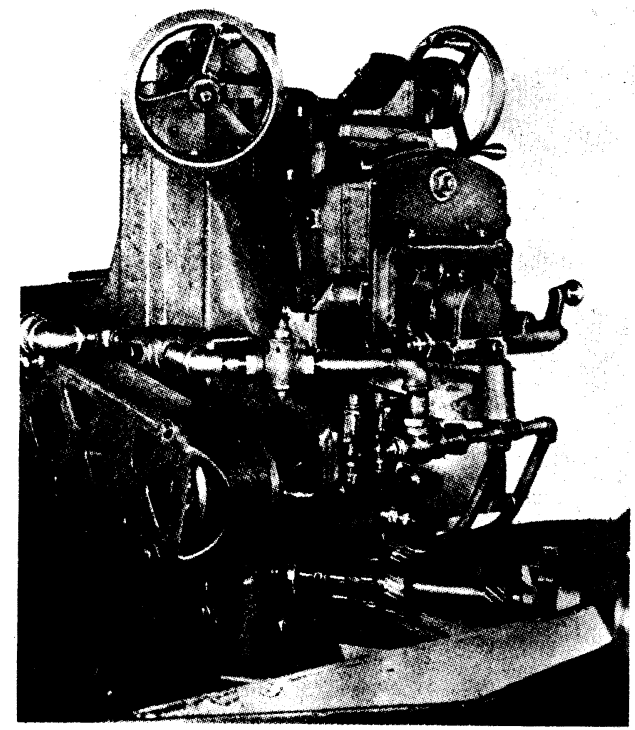

第 1 圆

の大きさの药車は traverseなしに grind でき る. 斜向醨車では少し困難である.小さい物で は特にさらである.小さい wheel 者使ふ方で は wheel は苳の面を traverse する. 斜向苳車 の時は traverse につれて萄車は伵らねばなら ぬ. 第 1 圖は Pratt \& Whitneyの gr.nderで, grinding wheel ばラムのへッドにつレてみ る. 同時に隣り合ふ二つの面衣 generateする ことができ，落車が完成すると機械は自働的に 止各.

Shaving は安價察進步した方法である.之は 萄の面上をそのプロパー・パスに沿ふて動くツ ールにより微細な shaving を取つて行く方法

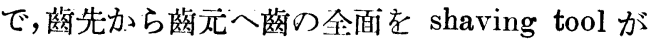
shave する.ラックの形のツールを使ふ物㐫あ
る・平苳車には傾斜したラックを，斜向苜車に は普通のラックを用みる.ラックが䔄車の下を 動き蒛車は伵轉すると共にラックの面を traverseする. Shaving はつながつてでき,その厚

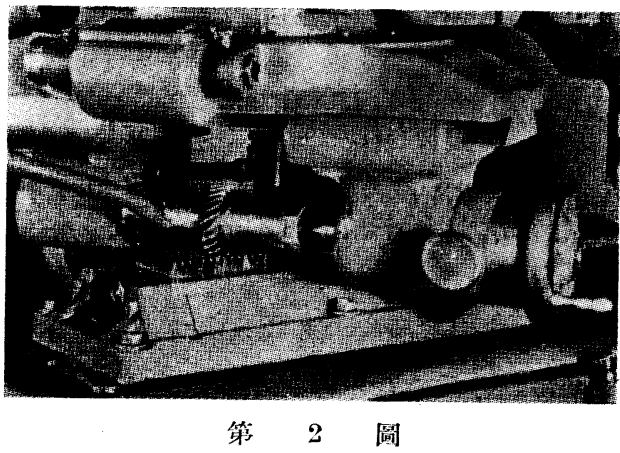

さは $0.002 "$ をを越すととは殆どなん．此種の機 械として Michigan Tool Co. の物を第 2 圖に 示す.

燒を入れ研磨された中央に溝のある工具鋼製 の铍物を使つてもよい. 溝は燒入後 elastic abrasive wheel で作られる.之においても平菌 車と科向菌車の組合せが用みられる.溝の网側 の銳レェッジが shaving 老行ふ。觜車はカッ夕 一と接觸して趣ると共にカッターの面を tra-

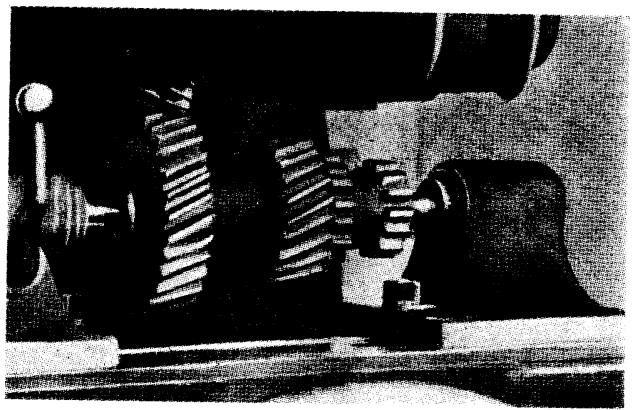

第 3 圖

verse する・苳車とカッターとは别に連結せら れて動いてみるわけではない，茲車をの世るテ

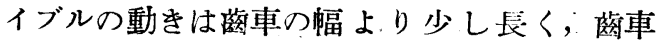


の 1 备轉每に動く方向が逆になる.媱車とカッ ター之の間に $10^{\circ}$ 乃至 $15^{\circ}$ の角度がある時が 丁度よレ。必要ならばコーダル・シックネスで $0.005 ”$ まで取去り得るととが要求せられる。 第 3 圖は National Broach \& Machine:Co.の 機械である。

らまくカットされた苳車は shaving によれ ば finishing eut の 10\%の時間で仕上ること ができる。

きれいな面を得たいと言ふとと及び燒入後の finishing の雼の費用とその必要性に對する疑 問から lapping が發達した. 今や之は標準的 となりつ〉ある・どの種の機械でも苳車は趣轉 し，藩車とラップの間の長さの方向の運動を確 實にする樣に設計されて居る・伵轉と往復との relative speed を變へて lapping action を確 實にすることができる，或種の機械では㑼車だ

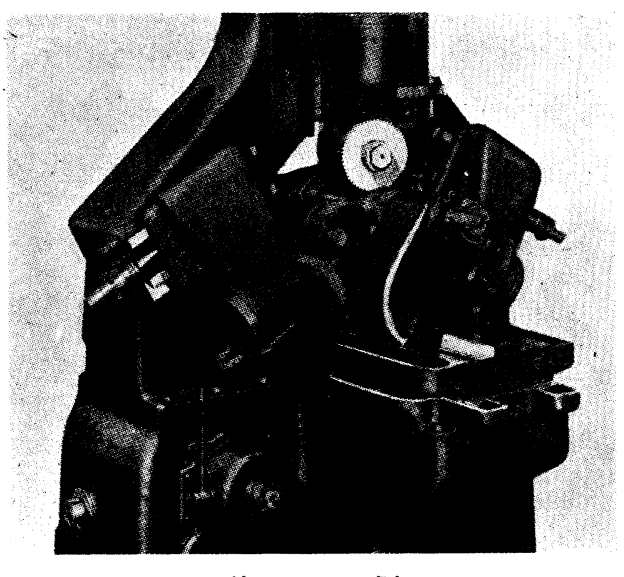

第 4 圖

けが d ive される. 3 箇のラップを用みる時 にはラップの苳數をかへる人もあるが，之は不 必要であると考へる者もある・第 4 圖に示す Michigan Tool Co.の機械は 3 籄のラップを用
みる・各ラップは別くのへッドに支へられ獨立 に調整するこ上ができる・蒛車をのせるテイブ ルは前後に動く

インコラップ・プロセスと言はれる方法があ る.作ららと思ふ蔽車と同形の鋼のチルを用み た chilled casting のラップを使ふ. その長さ は萄車の數倍ある・斜向茼車の lapping には落 車はカムによつてラップの中を正しい helix angle に保をれて往復する.ラップは charge はされぬが研裙劑はペイストにして刷子で與人 られる・蓬車は上下に動く、豫定數のストロー クを終ると苳車はラップからぬけ出て齐望の蒛 數だけ廻される。第 5 圖に示す機峨では 100 回

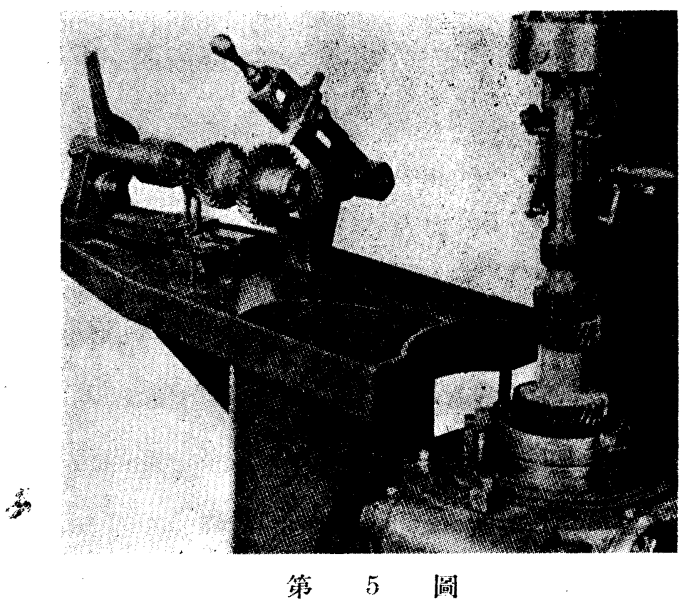

のストロークの後に斗备轉し, 次の 100 ストロ ークで lapping は終る・ストロークの數の多 い程 uniform な正確な苜車ができる・この方 法では齒の端の方が常に少し餘計にラップされ る.ラップは夫を通つた苳車の數之共に正確さ がますと言はれてみる・正常の程度にカットさ

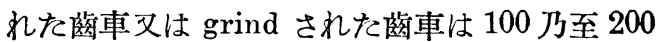
包のストロークで滿足すべき修正ができたとし てよい.ラップする蔽車の數の少い時又は例外 
的に細い仕上をする時にはタイプ・メタルのラッ プを使ふがよい. 各ストローク每に苳車を趣す ことの不必要であることは經驗せられてるる。 文ストロークは短くてよん：近頃の機械では
$3 / 8^{\prime \prime}$ 乃至 $4^{\prime \prime}$ である. 速さは $1 \mathrm{~min}$ に 120 乃至 200 ストロークである。

（中川淸次）

\section{Mach 氏屈折干涉計の一應用}

(Zeit.f. Tech. Physik Nr. 8. 1933)

1891 年に L. Mach 氏と之と獨立して Zehnder 肬とに依て發表された屈折干涉計の樣式 は大きな目的物から干涉縞を作るのに適してな る. 郎例へば重ねた硝子板から常に張力の加つ てるるものを計るとか，水力學丈は熱水力學の 現象とかを計るのである・此の方面の仕事には 完成された裝置が僅かである・近年になつて Zeiss といふ名で新しい裝置が現れた.として 悲しい事には獨逸には他に完成された見本がな レ. Nauheim 氏の報告ではどの方法で干涉縞 を執るのが效果があるかに就て，理論的の基礎 を說明して後實例を示してるる．Mach 氏自身 は點光源に依て属折干涉計の作用方法を單に公 表してねる．賽際に於ては廣大なる光源の使用 を强ひられるのであるが，複雜せる關係があつ て, 點光源は相應しん干涉縞を一般的に互に消 し合ふ.が或る條件下に裝置を調整すると干涉 縞が定まつた場所に明に出て來る. Hausen 氏 は此の問題の研究に從つた最初の人である.

Nauheim 氏の報告では廣大な光源で干涉縞の 成功が，殊に縞の明にある平面の存在が Mach 氏の考案の繼續で細に取扱はれてるる・之は報 告の第2章に委しく書いてする。實は原理に於
ては之が篤に必要な基礎は既に Mach 氏が書い てみるのである．佮今迄に系統的に實際的方法 を述べた著述が不足してるるのは遺憾である。

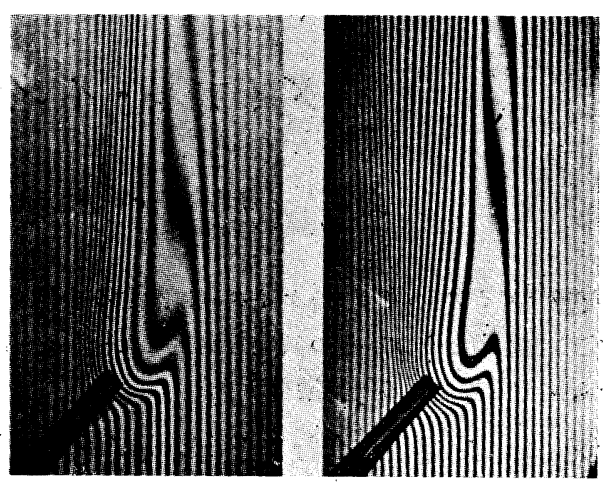

第 1 圆
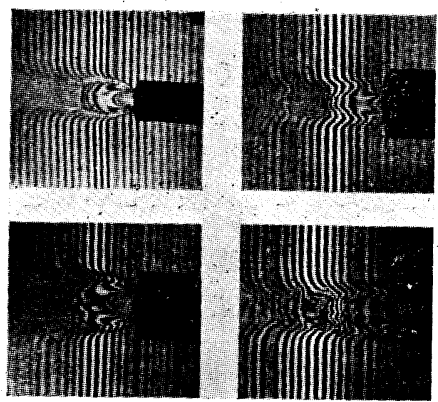

第 2 圖

實例として第 1 圖は縞の動きが示されてな る. 之は小さな瓦斯焰にょるるのである. 左手 の投光は普通の are lamp で右手のは blue filter 


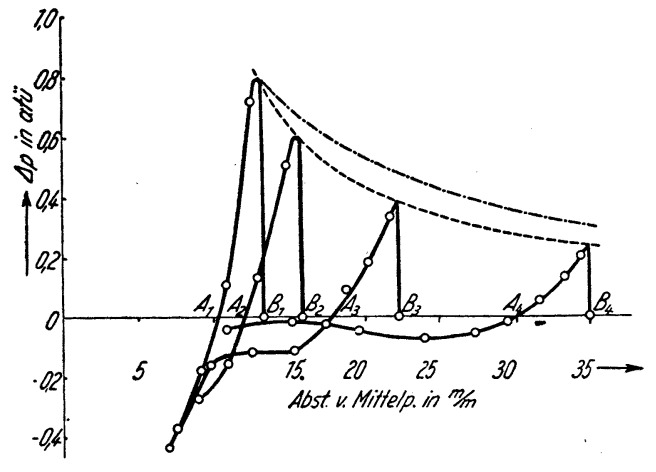

第 3 圆 Amplitude の減衰 (-ー-ー) は普通の 球狀の波より急である. Wave front の抚張速度 は音速より大である。(AB距離は expansion 大 なるによつて大となる)

を通路に入れたるのである・第 2 圖は壓縮空氣
を cylinder 形の blast より放出させたもので， blast からの現象は二三實際的の價值のある熱 學的問題に益する所が多い. そして之等は屈折 干涉計の助けでよく研究されるのである. 第 3 圖は球狀の爆發波の進行の時間之壓力之の經過 である，振幅は急に下り丁度普通の波が減衰す るのと同樣である. Wave front の狀態の變化 は斷熱的でなく恒熱的の樣である.

委しい報告は加熱管つ附近の熱の狀態や, 㱏 速以上で飛ぶ彈炕周圍の密度等を與へて る. 之は科學雜誌 “Zeitschrift für Instrumentenkunde” 飞㐫る. (早川誠之助)

\section{ダイアル・インディケイターの規格}

(Feinmechanik und Präzision, 1. März, 1933)

梗摡 ダイアル・インディケイターに對する規格を 定める基礎として,その誤差を測定した結果を述 ご適當と思はれる規格案を示す.

测角器 (度盛器を含む) と Fühlhebel との規 格は未だ DIN で定められて居なん. Fühlhebel のらちダイアル・インディケイターは各會社と も大體その構造を同じくし，その精度に對し購 買者と販䝴者との間に意見の相違があるから， その規格を定めることは䍿ましいととである。 この目的の基礎に役立てる雼 IMA て於て 8 䇢 のダイアル・インディケイターの誤差を測定し てみた・古い型新しい型各 4 简宛をとり・ブロッ ク・ゲージ及びスクルー・マイクロメーターを 用みてその誤差或ひは指示に對する補正值を求 める.ブロック・ゲージによればそれの持つ誤 差が問題とならぬ長所があるが，ゲージを取換
へる時常に同じ樣な接觸を测定面がせぬととか ら誤差の生ずるおそれがある・マイクロメータ 一ならば測定軸は常に同じ方向に連續的に推さ れるが，その補正は土 $1 \mu$ の精度で與へられて 居るに過ぎず, ダイアル・インディケイターの 誤差限界と同程度である（普通のインディケイ ターは最小目盛 $1 / 100 \mathrm{~mm}$ でその $1 / 10$ まで讀 むとする).

6 簀のインディケイターを兩方の方法で $1 \mathrm{~mm}$ 每に誤差を求めた結果は第 1 表及び第 $1 \mathrm{a}$ 圖,第 $2 \mathrm{a}$ 圖 及び第 3 圖である・示してある數值は多 くの測定の平均值で，圖は示してないが他のイ ンディケイターについても同樣な圖が得られる. 表に見る樣に全测定範圍の誤差の振幅が二つの 方法で $1 \mu$ 位の差しか與へぬばかりでなく, 誤 
第

1

表

\begin{tabular}{|c|c|c|c|c|c|c|c|c|}
\hline \multirow{3}{*}{$\begin{array}{l}\text { Meß- } \\
\text { uhr }\end{array}$} & \multirow{3}{*}{$\begin{array}{c}\text { MeB. } \\
\text { bereich } \\
\mathrm{mm}\end{array}$} & \multicolumn{6}{|c|}{ Amplitude der Fehlerkurve (in $\mu$ ) bei Prüfung innerhalb } & \multirow{3}{*}{ Abb. } \\
\hline & & \multicolumn{2}{|c|}{ Gesamtmeßbereich } & \multicolumn{2}{|c|}{1 Umdrehung } & \multicolumn{2}{|c|}{ 1/10 Umdrehung } & \\
\hline & & m. Endm. & m. Schrl. & 1. Messt. & 2. Messt. & 1. Messt. & 2. Messt. & \\
\hline $\begin{array}{l}\text { A } \\
\text { B } \\
\text { C }\end{array}$ & $\begin{array}{r}10 \\
10 \\
5 \\
10\end{array}$ & $\begin{array}{l}19,5 \\
.25,5 \\
132 \\
32\end{array}$ & $\begin{array}{l}18,5 \\
26 \\
14,5\end{array}$ & $\begin{array}{r}10 \\
6\end{array}$ & $\begin{array}{l}8 \\
8,5\end{array}$ & 3,5 & $\begin{array}{l}4,5 \\
8\end{array}$ & 1 \\
\hline $\begin{array}{l}\mathrm{E} \\
\mathrm{F} \\
\mathrm{G} \\
\mathrm{H}\end{array}$ & $\begin{array}{l}10 \\
10 \\
5 \\
10\end{array}$ & $\begin{array}{r}12,5 \\
7,5 \\
13 \\
8.5\end{array}$ & 13,5 & $\begin{array}{l}11 \\
5,5 \\
10^{11}\end{array}$ & $\begin{array}{c}13 \\
4,5 \\
11\end{array}$ & $\begin{array}{l}4 \\
5 \\
7,5\end{array}$ & $\begin{array}{l}3,5 \\
5 \\
4\end{array}$ & 2 \\
\hline
\end{tabular}

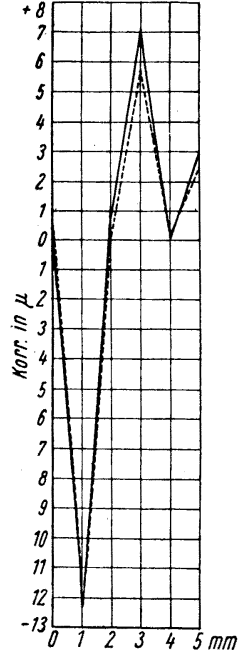

a

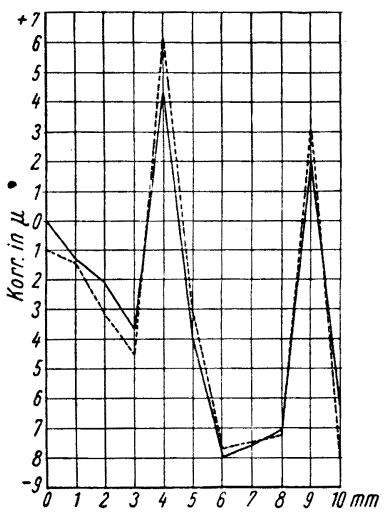

a

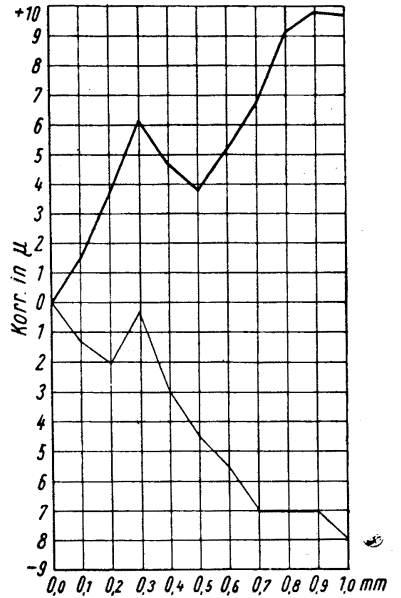

b

第 1 圖
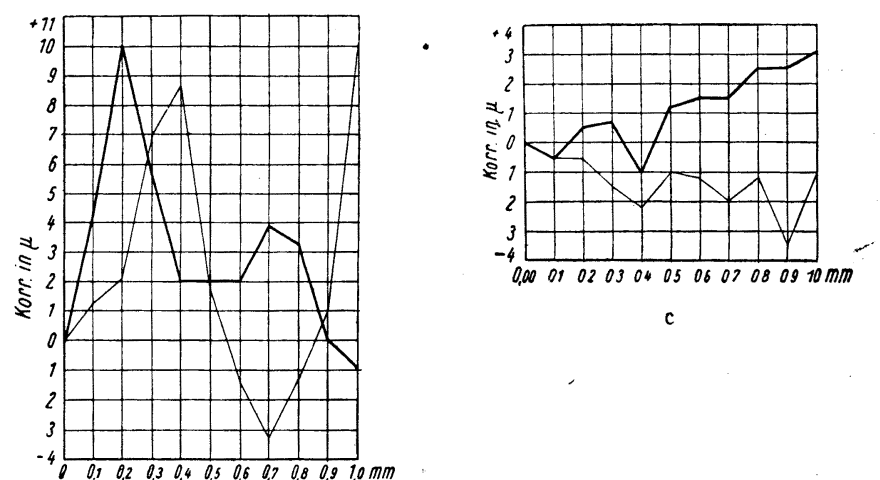


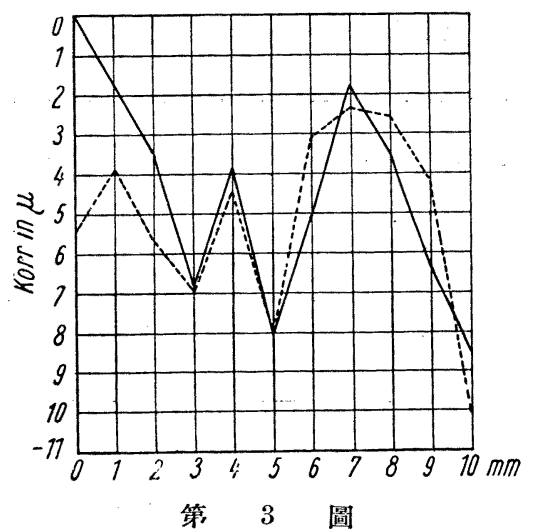

差曲線の傾向\&测定誤差の範圍內で一致してお る. H だけは例外で，始めの方に $5.5 \mu$ の差が ある. インディケイターが IMA の物でないか ら分解してその原因をしらべるととができぬ が，ピニョンヌはラックに引か」る所があるの であらう.

製造者がどの方法で檢定を行ふかは, 製造者 の任意であるが，公の檢定にはブロック・ゲー ジを使用するやうになるものと豫想した方がよ n.

どちらの方法でも同じ結果を得るととが分つ たから之から先の研究はブロック・ゲージによつ てのみ行つた・測定範圍內の 2 個所で，指針の

1 伵轉及び $1 / 10$ 趣轉の間の誤差を求める之第 1 表及び第 1 圖, 第 2 圖 b,c の樣である. 2 個所 の誤差曲線の振幅の差は $1 \mathrm{~mm}$ については $2 \mu$, $1 / 10 \mathrm{~mm}$ につんては $1 \mu$ でる。
第 1 表から近年ダイアル・インディケイター の進步したことが認められる・郎ち全测起範園 の間の誤差の振幅は2/100〜3/100mm から 1/100 〜 15/100mm に移つて居る.之はラックの製作 が良好になつたてとを示すが，ピニョンの方に はたいした進步のないことも表から分る。

さて以上の結果からダイアル・インディケイ ターの公差を如何にしたらよいかを考へる. ス クルー・マイクロメーターに對すると同㥞に許 し得る誤差の振幅をきめるのが良い方法で, 正 負として兩側に與へるか，正丈は負のいづれか 一方に限るかはどちらでもよいであらう。誤差 の振幅は全測定範圍，指針の 1 伵轉及び $1 / 10$ 廻轉に對して別ふに與へた方がよい。それはダ イアル・インディケイターは一般に狹い範圍で 使用されることが多いからである・第2表の如 き值は先づ公差として適當なものであらう. 之

$$
\text { 第 } 2 \text { 表 }
$$

Vorgeschlagene Toleranzen.

\begin{tabular}{c|c|c|c}
\hline \multirow{2}{*}{ Klasse } & \multicolumn{3}{|c}{ Bei Prüfung über den } \\
& $\begin{array}{c}\text { ganzen Meß- } \\
\text { bereich }\end{array}$ & Umdrehung & Umdrehung \\
\hline \multirow{2}{*}{ I } & 1,0 & 0.8 & $0.5 \mathrm{Skt}$ \\
II & 1,5 & 1.2 & $0,8 \%$ \\
& oder 2,0 & 1.5 & $1,0, \ldots$ \\
\hline
\end{tabular}

は或る會社がその製品に與へて居る保證と一致 して居るし, 叉 N.P.Lの許して居る最大誤差 とも一致して居る.（中川清次） 


\section{ゴム化合物の疲勞試驗機}

(Indust. and Eıgg. Chemistry Sept. 15, 1933)

概要 厭縮して屈曲されるときの疲勞抵抗による ゴム化合物の破壤郎 blow out される性質は常に 重大な問題であり，ゴム工業のすべての方面に於 る重大なる制限值となつてるる. Americaの Fireston Tire \& Rubber Company の工場で最 近ゴム化合物の疲勞抵抗を測る新しい機械が作り 出された。

此の型の以前の機械は常に大きな車郎 drum があり，その上で tire が破壤されるのであつ た. 又研究空州機械は數が多く且好成䋶でもな かつた. Schopper 氏（註1) の磨耗試驗機は 小球の形のゴム塊の疲勞及磨滅試驗用の研究室 用であるし.Abbot 氏(註2) のはゴムを振動

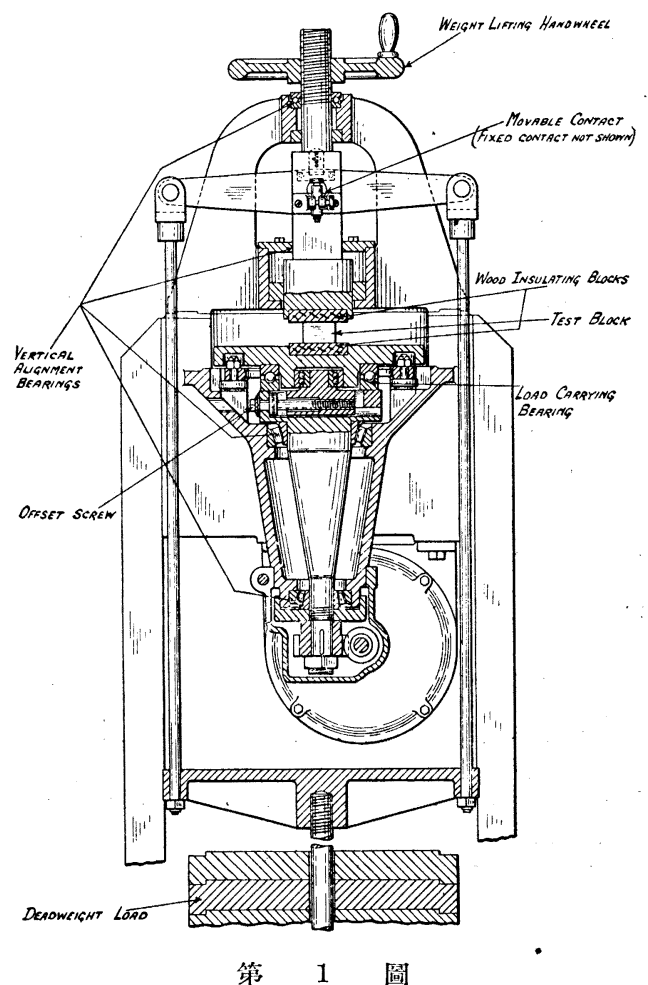

吸收用に用ひた試驗に於て blow outを得た。 以桃多くの提案に依て如们に正確に疲勞抵抗が 研究室的に評價さる可きかが進步した. 最近の 設計は Fireston 社の技師である R. W. Allen 氏に依てなされ（第1 圖),彼の名で此の屈曲計 の特詐をとつた。

此の計器の寫黄は第 2 圖に示す通りである. 此の屈曲計は研究室用試驗機であるが，锍暴に

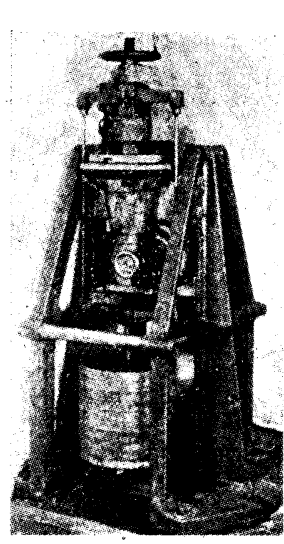

第 2 圖 續けて使用しても差支 ない樣に設計されてる る・此の機械の作用は 定まつた荷重の下で壓 縮するな゙けでゴム塊は 二つの板の間に入り 1 枚は固定で他の 1 枚は 定まつた大んさの圓運 動をする・その速さは 1 分間 800 振動ですべ ての條件の下で一定である. 荷重と圓運動の大 レさは廣い範圍に變化する，機械は定める塊に 對して可能性の制限值がないからどの壓縮に對 しても作業され得るであらう。

用ひられる試驗塊の形は截頭四角 錐で底は $2.125 \times 1.125 \mathrm{inch}^{2}\left(5.40 \times 2.86 \mathrm{~cm}^{2}\right)$, 頂は $2 \times 1$ inch $^{2}\left(5.03 \times 2.54 \mathrm{~cm}^{2}\right)$ である. 此の傾きのある 形は完全なる塊がどんな塊の type からでも用 意される樣に選ばれたのである。一例として， 亞鉊酸化物を多く含む化合物は高溫で非常に 
brittle でする. 若し此の樣な試驗塊が粘着する 性質があるなら，鑄型から制ぐときに駄目にな るかも知れぬ・乾燥された試驗塊からはどの樣 な寸法でも形でも切り出せるが，高さは $2 \mathrm{inch}$ 以下でなければならぬ.之は板の間の最大距離 が 2inchであるからである・傾きのある試驗片 は試驗見本が研究室で乾燥されねばならぬとき に限り用ふるのである.

使用方法 試驗塊が作られてからの機械の使用 方法は次の通りである.

1）振動板を死點の上にのせて是まつた出發溫 度にする。

2）試驗塊を振動板上にのせ荷重板のすぐ下に 置く、之等の板の中央には木が押込まれて ある. 3inch (7.62em) 直徑で 0.50inch $(1.27 \mathrm{~cm})$ の厚さのもので, ゴム塊は木片の 間に置かれる・木片は熱の絕緣體で試驗塊 に發生したすべての熱を保つ樣にする。

3）荷重は試驗塊に手車を䞤はす事によつて掛 けられる・そして試驗塊で支へられ手車の thrust bearing で支へられなくする.

4）荷重を掛けた後の試驗塊の高さが测られ屈 曲が計算される。

5）振動板は中心より與へられた大いさだけ外 れて取付られ試驗塊を傾ける截頭绝角錐に 變化させる・作業中に振動板に依て示され る圓の直徑は，“throw”といはれる.

6) 電氣的の bell-rining contact が或る定ま つた距離だけ離れてるる樣に調節される。 此の始めの contact 間の距離を “ signal distance”之云ふ. 試驗塊が試驗作業中に 屈曲して, 上の contact が段々と下る.
之は荷重が常に試驗塊に加つてなるからで ある.之の下行する運動は多くの試驗に上 り, 試驗塊の中心の狀態によつて等まるも のである事が分つた・即同じ成分の化合物 はすべて同じ距離で yieldする. 郎 signal distance で porosity が始まる時に yield する・試驗作業を更に繼續すれば，試驗塊 は blow out し，粉々に引き裂かれて了 ふ. Slightly porosity の yield する距離 を定めるのは之を防ぐ篇である。

7）試驗時間は圓運動が始まる時から bell が 鳴るときまで测るのである. そして bell は electrical contact が closeする程, 試驗塊 が變化しないと鳴らぬのである。

此の作粟は blow out する抵抗を䇥める・溫 度上昇や發生せる熱等は thermo conple を挿入 して或る程度の仕事が試驗塊に對して受された 時に测るのである。

一人で以てょく5臺の機械を作業させられ る. 若し自働制動機があるならば，一つの機械 はその作業者がしてなる他の仕事を邪魔する事 なしに㗢く事が出來よう.

唯よく moldされた塊を得又䇥めるのに時間 を正しくする必要がある. 若しさうしたら常に 同じ結果が得られるだらう. 此の機械は設計も 運動も複雜でをいから，色々を方面の試驗て容 易に用ひられる。

結果 此の機械に依て得た結果の例として，六 つの特殊な化合物が作られ試驗された. その結 果を第 1 表と第 2 表に示す. 
第 1 表

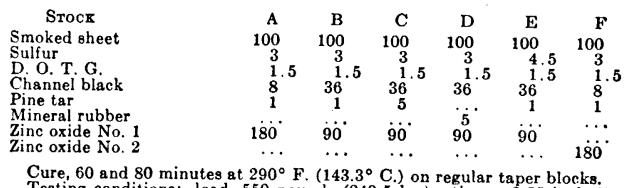
Cure, 60 and 80 minutes at $290^{\circ} \mathrm{F}$. (143.3 $3^{\circ} \mathrm{C}$.) on regular taper blocks.
Testing conditions: load, 550 pounds $(249.5 \mathrm{~kg}$.); throw, 0.55 inch (14
mm.); signal, 0.300 inch $(7.60 \mathrm{~mm}$.)

\section{第 2 表}

\begin{tabular}{|c|c|c|c|c|}
\hline $\begin{array}{l}\text { STOCX } \\
60-\end{array}$ & HARDNESS & & TIME UNTIL & Condirion or \\
\hline$\underset{\text { cure }}{\operatorname{minute}}$ & $\begin{array}{c}\text { 3-Pound } \\
\text { Penetrometer }\end{array}$ & Deflection & $\begin{array}{l}\text { BELLL } \\
\text { RANG }\end{array}$ & $\begin{array}{c}\text { STOCK AFTER } \\
\text { TEST }\end{array}$ \\
\hline & 0.001 in $^{a}$ & $\%$ & Min. & \\
\hline $\mathrm{A}$ & 43 & 23.3 & 53 & Slightly porous \\
\hline$\stackrel{\mathrm{B}}{\mathrm{C}}$ & $\begin{array}{l}35 \\
35\end{array}$ & $\begin{array}{l}22.3 \\
23.3\end{array}$ & $\begin{array}{l}16.5 \\
10.5\end{array}$ & $\begin{array}{l}\text { Porous } \\
\text { Porous }\end{array}$ \\
\hline D & 35 & 22.7 & 17.5 & Porous \\
\hline$\underset{F}{\mathrm{E}}$ & 30 & $\begin{array}{l}18.0 \\
22.7\end{array}$ & $\begin{array}{l}19.5 \\
31\end{array}$ & $\begin{array}{l}\text { Porous split } \\
\text { Slightly porous }\end{array}$ \\
\hline $\begin{array}{l}80- \\
\text { minute }\end{array}$ & & & & \\
\hline & & & & Slightly norou \\
\hline$\underset{B}{A}$ & $\begin{array}{l}46 \\
35\end{array}$ & $\begin{array}{l}22.3 \\
22.3\end{array}$ & $\begin{array}{l}85 \\
16\end{array}$ & $\begin{array}{l}\text { Porous } \\
\text { Porous }\end{array}$ \\
\hline C & 33 & 23.0 & 10.5 & Porous \\
\hline $\mathrm{D}$ & 35 & 22.7 & ${ }_{20}^{17}$ & $\begin{array}{l}\text { Porous } \\
\text { Porous split }\end{array}$ \\
\hline $\mathbf{F}$ & 40 & 22.7 & 39 & Slightly porous \\
\hline
\end{tabular}

註 1) Schopper; Louis, Catalog 415, p. 25, Leipzig, Germany; American Agent, Testing Machine, Inc., New York, N. Y.

2) Abbott, IND. ENG. CHEM., 20, 853-7 (1928)

（早川誠之助） 